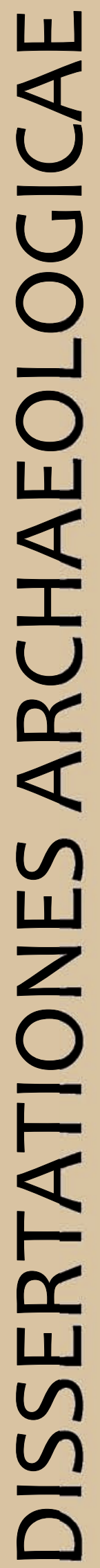

ex Instituto Archaeologico Universitatis de Rolando Eötvös nominatae

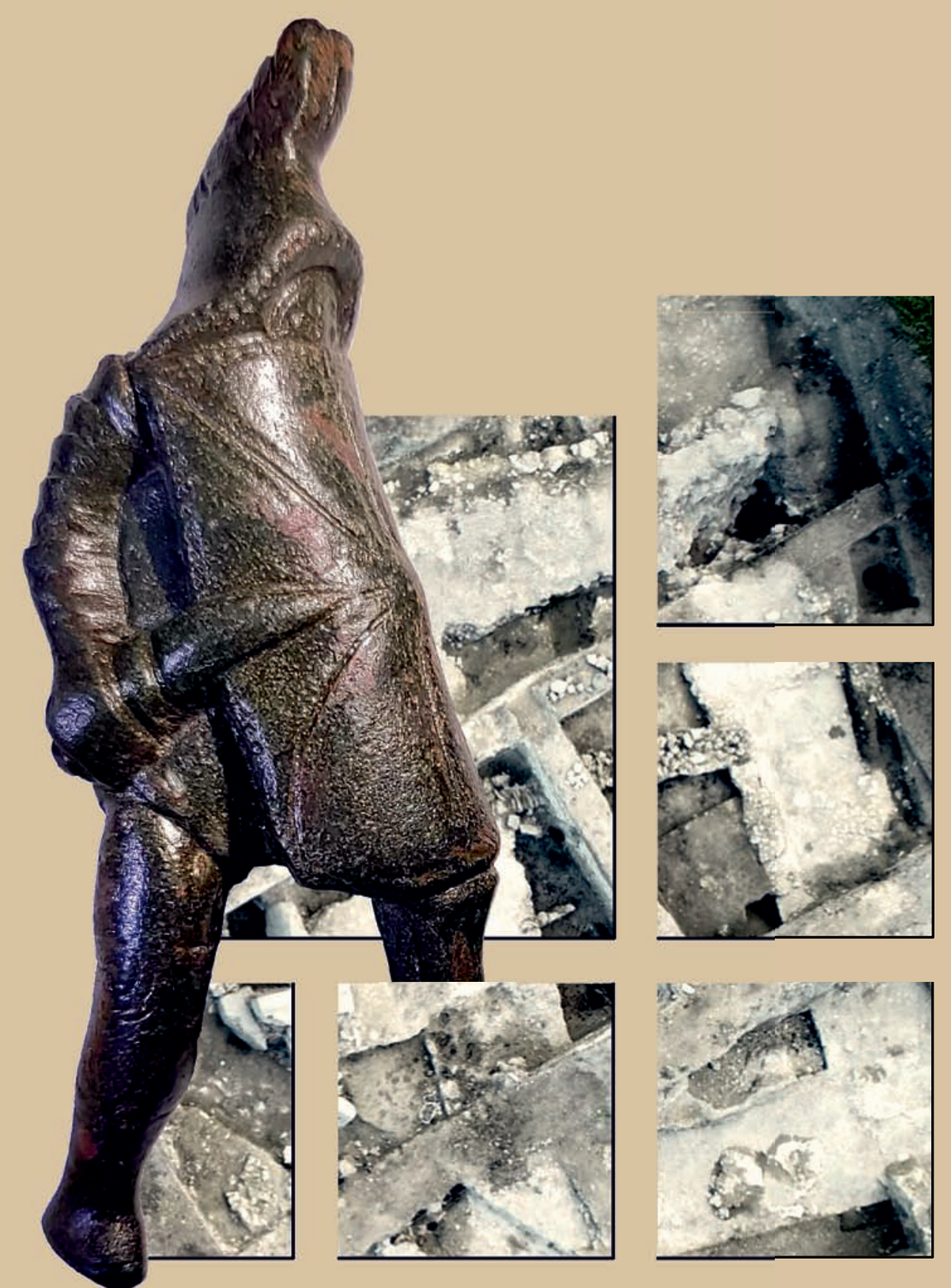

$$
\text { Ser. 3. No. 7. } 2019
$$




\section{Dissertationes Archaeologicae ex Instituto Archaeologico}

Universitatis de Rolando Eötvös nominatae Ser. 3. No. 7.

Budapest 2019 
Dissertationes Archaeologicae ex Instituto Archaeologico Universitatis de Rolando Eötvös nominatae

Ser. 3. No. 7.

Editor-in-chief:

DÁvid BARTUS

Editorial board:

LÁsZló BARTOSIEWICZ

LÁSZLÓ BORHY

ZOLTÁN CZAJLIK

IsTVÁN FELD

GÁBOR KALLA

PÁL RACZKY

MikLÓs SzABÓ

TivadAR VidA

Technical editor:

GÁBOR VÁCZI

Proofreading:

SZILVIA BARTUS-SZÖLLősI

ZsóFIA KondÉ

Aviable online at http://dissarch.elte.hu

Contact: dissarch@btk.elte.hu

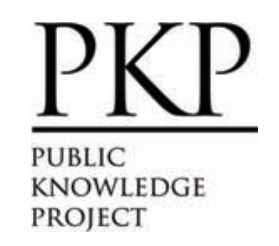

๑ ELTE Eötvös Loránd University, Institute of Archaeological Sciences

Layout and cover design: Gábor Váczi

Budapest 2019 


\section{CONTENTs}

\section{ARticles}

János Gábor TARBAY

The Casting Mould and the Wetland Find - New Data on the Late Bronze Age

Peschiera Daggers

Máté MeRvel

Late Bronze Age stamp-seals with negative impressions of seeds from Eastern Hungary

János Gábor TARBAY

Melted Swords and Broken Metal Vessels - A Late Bronze Age Assemblage

from Tatabánya-Bánhida and the Selection of Melted Bronzes

Ágnes ScHNEIDER

Multivariate Statistical Analysis of Archaeological Contexts: the case study

of the Early La Tène Cemetery of Szentlörinc, Hungary

Csilla SÁRÓ - Gábor LASSÁNYI

Bow-tie shaped fibulae from the cemetery of Budapest/Aquincum-Graphisoft Park

Dávid BARTus

Roman bronze gladiators - A new figurine of a murmillo from Brigetio

Kata DÉvAI

Re-Used Glass Fragments from Intercisa

Bence Simon

Rural Society, Agriculture and Settlement Territory in the Roman, Medieval and Modern Period Pilis Landscape

Rita RAKONCZAY

„Habaner“ Ofenkacheln auf der Burg Čabrad”

\section{FIELD REPORT}

Bence Simon - Anita Benes - Szilvia Joháczi - Ferenc BARnA

New excavation of the Roman Age settlement at Budapest dist. XVII, Péceli út (15127) site 


\section{Thesis Abstracts}

Kata SzILÁGYi

Die Silexproduktion im Kontext der Südosttransdanubischen Gruppe

der spätneolithischen Lengyel-Kultur

Norbert FARAGÓ

Complex, household-based analysis of the stone tools of Polgár-Csőszhalom

János Gábor TARBAY

Type Gyermely Hoards and Their Dating - A Supplemented Thesis Abstract

Zoltán Havas

The brick architecture of the governor's palace in Aquincum

Szabina Merva

'...circa Danubium...' from the Late Avar Age until the Early Árpádian Age-

$8^{\text {th }}-11^{\text {th }}$-Century Settlements in the Region of the Central Part of the Hungarian

Little Plain and the Danube Bend

Szabolcs Balázs NAGY

Noble Residences in the $15^{\text {th }}$ century Hungarian Kingdom - The Castles of Várpalota,

Ujlak and Kisnána in the Light of Architectural Prestige Representation

Ágnes KollátH

Tipology and Chronology of the early modern pottery in Buda 


\title{
Type Gyermely Hoards and Their Dating \\ A Supplemented Thesis Abstract
}

JÁNOS GÁBOR TARBAY

Hungarian National Museum, Department of Archaeology, Prehistoric Collection

tarbay.gabor@mnm.hu

\begin{abstract}
Abstract of PhD thesis submitted in 2019 to the Archaeology Doctoral Programme, Doctoral School of History, Eötvös Loránd University, Budapest under the supervision of Gábor V. Szabó
\end{abstract}

\section{Introduction $^{1}$}

The dissertation titled as 'Type Gyermely Hoards and Their Dating' discussed Late Bronze Age hoards, which have been associated with the Horizon Gyermely (Ha A2, Hortfundstufe III, Jászkarajenö-Uzsavölgy Stufe) from the territory of Western and Eastern Hungary. ${ }^{2}$ The 'Hungarian Ha A2' is a contradict period that was interpreted as a transitional stage by the local research, which 'wedged' between two main periods, the Ha A1 (Horizon Kurd, Hortfundstufe II) and the Ha B1 (Horizon Hajdúböszörmény, Hortfundstufe IVa).

Starting from this 'transitional period', in the territory of the Hungary significant historical changes supposed to happen within three large cultural complexes, the Transdanubian Urnfield circle, the Eastern Hungarian Gáva pottery style and the North Hungarian Kyjatice culture. In the western territories, decline of hoarding traditions and settlement complexity can be seen, while in the Eastern regions a new and uniform pottery style have emerged and during the Ha B1, the quality and quantity of hoards increased, forming the Horizon Hajdúböszörmény. According to conventional theories, the hoards of the Horizon Gyermely are the archaeological heritage of this transition.

The identification of the Ha A2 period in the territory of the Carpathian Basin and Hungary based almost solely on the relative chronological position of hoards and metal finds. The chronological schemes of Amália Mozsolics and Tibor Kemenczei relied on the 1968 monograph of Wilhelm Albert von Brunn, which formulated the concept of transitional theory. ${ }^{3}$ In contrast, the Berlin school's head Svend Hansen assigned these some of these assemblages to the Ha B1. ${ }^{4}$ Peter Turk also rejected the 'transitional concept' and dated the Transdanubian Gyermely hoards to broader chronological units. ${ }^{5}$ According to the latest results of the Hungarian research, the discussed period also seemed to be dissolved in the territory of Transdanubia based on the analysis of individual hoards. ${ }^{6}$

1 The author of the thesis is currently working on the English publication of his dissertation. This thesis abstract is supplemented with a few new results derived from this work.

2 TARBAY 2018.

3 von BrunN 1968; Mozsolics 1985; KeMENCZei 1996 a.

4 HANSEN 1994, 397-406; HANSEN 1996.

5 TURK 1996.

6 TARbay 2014; VÁcZi 2014; TARbay 2015b. 


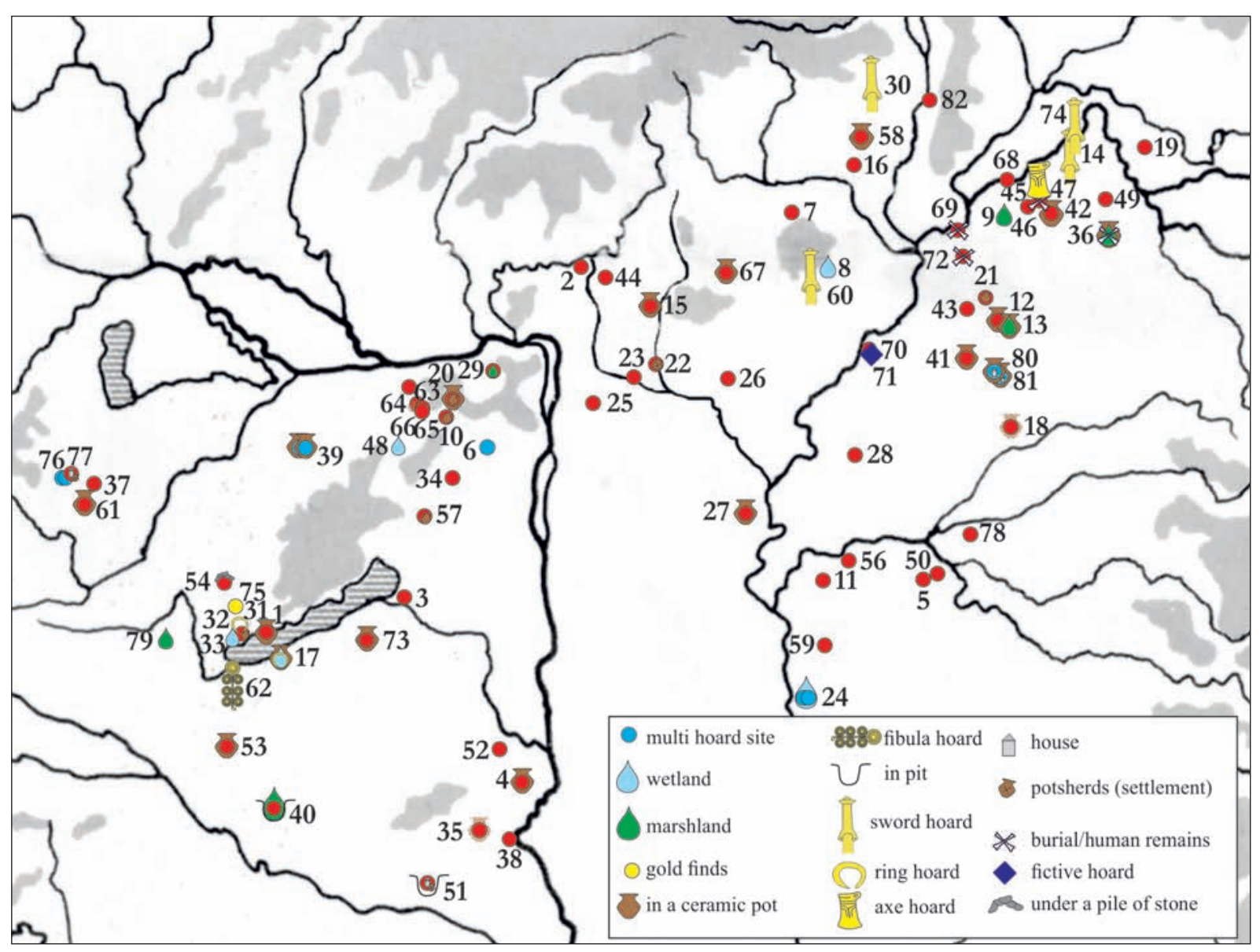

Fig. 1. Hoards studied in the dissertation: Badacsonytomaj-Köbölkút, 2 - Balassagyarmat, 3 - Balatonszabadi-Gamásza, 4 - Bátaszék, 5 - Békéscsaba, 6 - Biatorbágy-Herceghalom, 7 - Borsodbóta, 8 - Borsodgeszt-Kerekhegy, 9 - Buj-Fekete-halom, 10 - Csabdi-Bükkös erdő, 11 - Cserebökény, 12 - Debrecen-Látókép II, 13 - Debrecen-Dombos tanya III, 14 - Döge/Szabolcsveresmart, 15 Ecseg-Kozárdi hegy I, 16 - Edelény I, 17 - Fonyód II, 18 - Gáborján-Korhány halom, 19 - Gelénes/ Téglás I, 20 - Gyermely-Szomor, 21 - Hajdúböszörmény-Hetven-laponyag, 22 - Hatvan-PestLosonc-Beszterce vasútvonal, 23 - Hévízgyörk, 24 - Hódmezővásárhely-Fehértó puszta Ia-b, 25 - Isaszeg, 26 - Jászdózsa-Morvay tanya, 27 - Jászkarajenő, 28 - Kenderes, 29 - Kesztölc-Bodzás dủlő, 30 - Krasznokvajda-Zábráczky dủlő, 31 - Lesenceistvánd Ia, 32 - Lesenceistvánd Ib, 33 Lesenceistvánd ['Uzsavölgy'] II, 34 - Lovasberény, 35 - Máriakéménd, 36 - Mérk-Tiborszállás, 37 - Meszlen, 38 - Mohács, 39 - Nagydém-Gerha dúlő Ia-b, 40 - Nagydobsza, 41 - Nagyrábé I, 42 - Napkor-Ludas tó, 43 - Nádudvar-Bojárhollós I, 44 - Nógrádmarcal, 45 - Nyíregyháza-Ér alatti szőlők III, 46 - Nyíregyháza-Sertéskombinát V, 47 - Nyírpazony-Új szőlő, 48 - Oroszlány-Erőmű ['Bokod'], 49 - Pusztadobos, 50 - Sarkad I, 51 - Siklósnagyfalu ['Beremend'], 52 - SióagárdLeányvár I, 53 - Somogyszob, 54 - Sümeg-Papföld mező, 55 - Szabolcs-Szatmár-Bereg County, 56 Szarvas vidéke, 57 - Székesfehérvár-Szeder utca, 58 - Szendrőlád-Kőbánya tető, 59 - SzentesNagyhegy Ia-b, 60 - Szihalom, 61 - Szombathely-Jáki út, 62 - Szőkedencs, 63 - Tata-Dunamellék, 64 - Tatabánya-Bánhida I, 65 - Tatabánya-Bánhida II, 66 - Tatabánya-Ótelep III, 67 - Szajla [Terpes], 68 - Tiszabercel-Sárgadomb, 69 - Tiszalök-Újtelep I, 70 - Tiszaszőlős I, 71 - ,Tiszaszőlős II’ (fictive hoard), 72 - Tiszavasvári-Téglagyár II, 73 - Torvaj, 74 - Tuzsér, 75 - Várvölgy-Nagyláz-hegy [Felsőzsid] I, 76 - Velem Ia-b, 77 - Velem IV, 78 - Vésztő-Damjanich utca 6, 79 - ZalaszentmihályPötréte, 80 - Zsáka-Dávid tanya I, 81 - Zsáka-Dávid tanya II, 82 - Zsujta-Ortvány dűlő.

As there was no comforting consensus in the last decades about this hoard horizon, the firsthand re-documentation and re-analysis of the Hungarian Ha A2 hoards was an essential goal. To achieve this aim, systematic fine typo-chronological and wear analyses of 82 metal hoard 
assemblages have been done within the author's $\mathrm{PhD}$ work (Fig. 1). ${ }^{7}$ The selected finds included those Hungarian hoards which were previously identified as transitional ones by Amália Mozsolics (Horizon Gyermely) and Tibor Kemenczei (Hortfundstufe III), as well as some typologically related hoards from the Horizon Hajdúböszörmény (Ha B1). New assemblages, which have not been published in detail were also studied. The main goal of the dissertation was to take a stand on the topic of the Hungarian Ha A2 horizon and determine the relative chronological position of the hoard assemblages and characterize the objects selected to them.

\section{The 'Collapse' of a Hoard Horizon}

\section{A new catalogue}

The results of the dissertation were partly based on a catalogue, that included high-resolution photo plates, wear data and metrical description of the finds. Brief summary of the circumstances of discovery and the typo-chronological aspects and selection of the hoards were also added. Unlike former studies, which only dealt with hoards selectively, the thesis published the full content of each assemblages. This resulted an 'increase' of previously neglected objects like raw materials (plano-convex ingots, droplets, casting jets) and certain ornament types (e.g. Type Lovasberény rings).

\section{Source criticism}

An important factor in the analysis was source criticism. Authenticity of the contexts was re-evaluated by archive documents. Post-depositional effects on the hoards' content, technological profile, fragmentation and manipulation patterns were also analysed. The results of this approach were not at all positive. From methodological point of view, majority of the Hungarian assemblages associated with the Ha A2 are practically unsuitable for drawing representative conclusions on relative chronology. This statement is especially true for those assemblages that were acquired by museums from private collectors and antiquities dealers. The composition of these hoards showed serious gaps. As a result, the determination of their complete relative chronological pattern and their time of deposition was not possible. In certain cases, it is unclear why they were included in the transition horizon at all. Fine example is the 'allegedly Mohács' hoard, which the Hungarian National Museum (HNM) bought from Jakab Krausz antiquities dealer. According to József Hampel, the original hoard weighed ca. $15 \mathrm{~kg}$. It consisted of 12 socketed axes, 1 socketed hammer, 20 sickle fragments, 20 spearheads and several ingots and rings (Fig. 2.C). The HNM acquired the minority of the finds, which only 3 sickles, 3 socketed axes and 1 hair-ring has remained (Fig. 2.A). ${ }^{8}$ Nonetheless, Amália Mozsolics related it to the Horizon Gyermely and Tibor Kemenczei associated the finds with the Hortfundstufe III. ${ }^{9}$ The obviously incomplete hoard was even analysed by statistical methods

7 Unfortunately, one of the hoards turned out to be a fictive one, a few months after submission. Amália Mozsolics and Tibor Kemenczei cited both the 'Tiszaszőlős-Csákányszeg' (Tiszaszőlős 2) hoard from a glass negative stored at the Archives of the Hungarian National Museum (No. Ö 2399). This glass negative shows four socketed axes, and two knobbed sickles with the inscription of 'Tiszaszôloss, from a private collection'. Kemenczei 1984, 189, Pl. 209.c.1, 4-5; Mozsolics 1985, 205; Kemenczei 1996a, 78. The artefacts on the glass negative are completely identical in every details (e.g. size, shape, breakages, corrosion marks) with the objects from the Blatná Polianka (Slovakia) hoard. The axes and sickles from the Blatná Polianká hoard still have the original inventory numbers referring to the Slovakian site. See TARBAY 2019b, 316-319, Pl. 9-11.

8 Inventory Book of the Hungarian National Museum 1878, Inv. No. 1878.3.1-7; Hampel 1886, 48-49; Hampel 1892, 92; Holste 1951, 14, Pl. 23.19-24.

9 Mozsolics 1985, 150; Kemenczei 1996a, 77; Kemenczei 1996b, 233, 235, Fig. 6.6-12. 


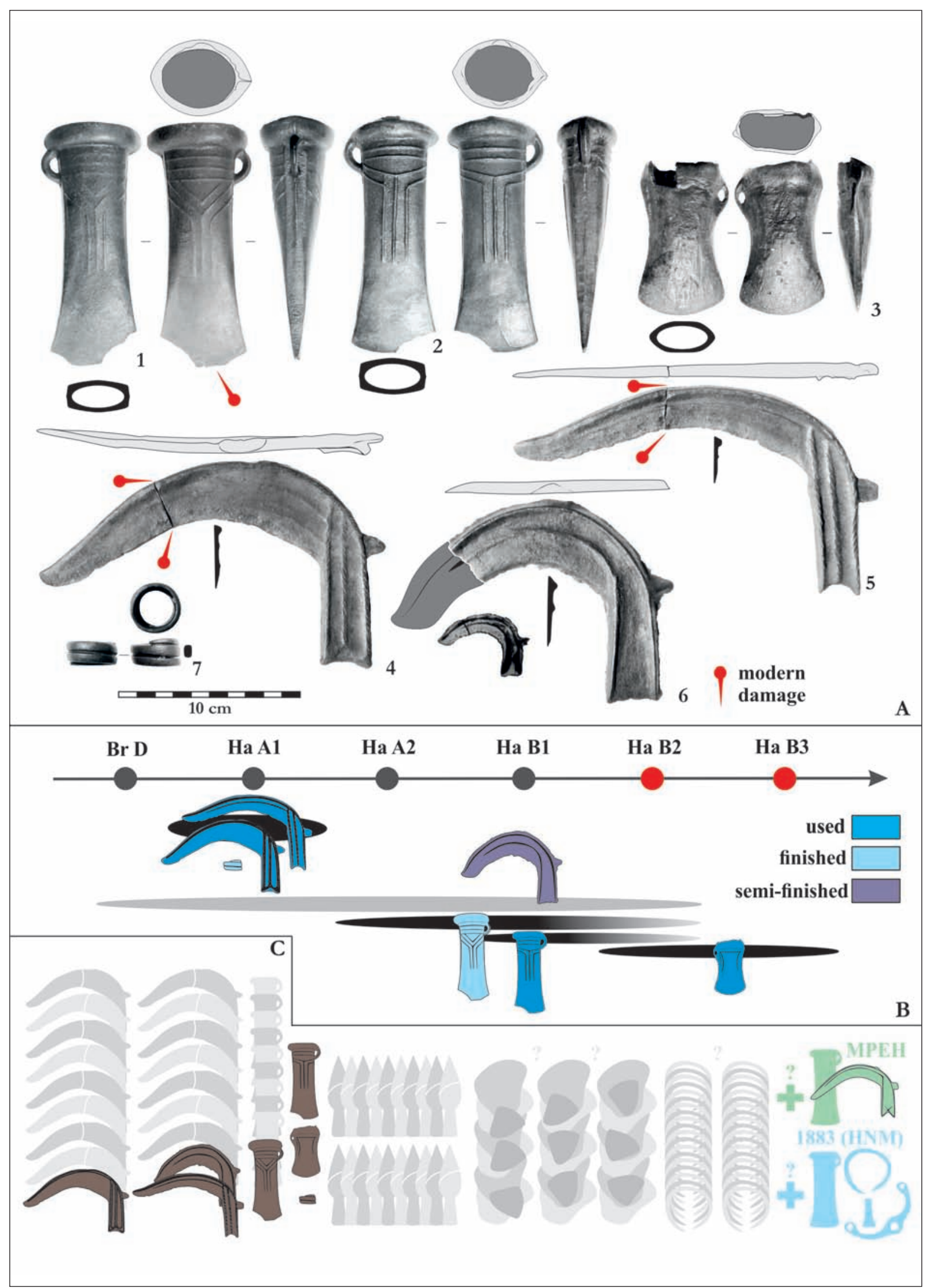

Fig. 2. A: Objects remained of the hoard from 'allegedly Mohács'. 1-3 - socketed axes, 4-6 - flanged sickles, 7 - hair-ring, B - Technological classes and relative dating of the finds, C - Reconstruction of the presumed composition of the hoard (after HAMPEL 1886, HAMPEL 1892; information provided by Bernhard Heeb via e-mail). 
in the recent monograph of Olimpia Bratu. ${ }^{10}$ The results of typo-chronological analysis based on the 'allegedly Mohács' hoard's complete group of parallels also argues against the Ha A2 dating. The complete relative chronological interval of the finds covers the time between the $\mathrm{Ha} \mathrm{A} 1$ and $\mathrm{Ha} \mathrm{B} 2 / \mathrm{Ha} \mathrm{B} 3$. The time of deposition, if these finds were at all belong together was the Ha B2/Ha B3 based on No. 3 axe (Fig. 2.B).

\section{Systematic metalwork wear analysis}

The material was studied by microscope-camera images and high-resolution photographs. It focused on the identification of manufacturing techniques, usage and fragmentation traces. This approach allowed the characterization of the objects' life cycles, hoard selection and to draw conclusions on general technological patterns.

The selection of the studied hoards were not uniform. In addition to ingots, as-casts, untreated casts, semi-finished products, finished products, used, modified or even secondary used objects could be selected to these hoards. The object selection was individual and varied in each hoard. Although, it seems that the deposition of finished products beside ingots were dominant. A fine example is the Tatabánya-Bánhida II hoard. Based on the wear analysis, it consisted of raw materials, by-products, untreated casts. Also several finished products were selected to the hoard, some of which showed even traces of use. Most objects went through intentional manipulations by different methods (breakage, bending, blade impacts, objects combination) (Fig. 3).

The selection of as-casts, semi-finished products were typical in hoards that included also various ingots and casting by-products. Certain objects were almost completely selected without any further post casting treatment. Such finds are the Type Palotabozsok axes, which were either ingots or they were directly cast before the act of deposition, or they have been made intentionally for the deposition act.

Objects showed differences in their post-casting treatment. Fine manufacturing traces were visible on weapons, ornaments and special finds (e.g. decorated knives). These products were part of the personal representation. Thus, their aesthetic appearance was also important to their owners. In contrast, the manufacturing traces on 'mass products' like socketed axes or sickles were superficial and it was observable mainly on the functional part of the objects (e.g. blades). Their purpose was to make the objects suitable for use, the appearance of product was less important. Casting defects and manufacturing errors were also observed. We can conclude that the Late Bronze Age defect tolerance was much higher than in modern times. Some of them (e.g. mismatch) were repaired during the post-casting treatment phase, while others, especially aesthetic ones were generally ignored (misrun, core shift, amorphous cast patterns, shrinkage, minor porosity). Only those finds were not manufactured further which defect (e.g. core rising, incomplete casts) did not allowed the objects to be used. Several of the cast defected artefacts were manufactured as finished products and even showed traces of use.

Against many serious source critical problems (e.g. outdated restoration, modern damages and use occurred at the time of discovery or in the museum collections), the analysis of wear traces was also possible. Use-wear analysis was particularly effective on cast objects which provided the core data of the studied material. Based on these results, it can be stated that

10 Bratu 2009, 304, No. 692. 
almost all hoards contained finished products. On better preserved specimens it was also possible to document different traces of use. In several cases these objects indicated a quite long use-life. Fine examples are the re-shaped spearheads, the secondary hilted sword and those sickles, knives and axes which were used to their maximal life-span or the hammers made of broken socketed axes. Characteristic abrasion traces were also visible on ornaments. Rings had worn surfaces and chased patterns, fibulae and belt hooks were repaired. It is plausible that these ornaments were personal sets used by their owners until their death or inherited from generations to generations before their deposition.

The fragmentation and manipulation patterns of the hoards were also subjected to study. In general, it can be stated that manipulation practices (bending, object combinations, blow, etc.) are primarily related to object types. Their form and way of execution was influenced both

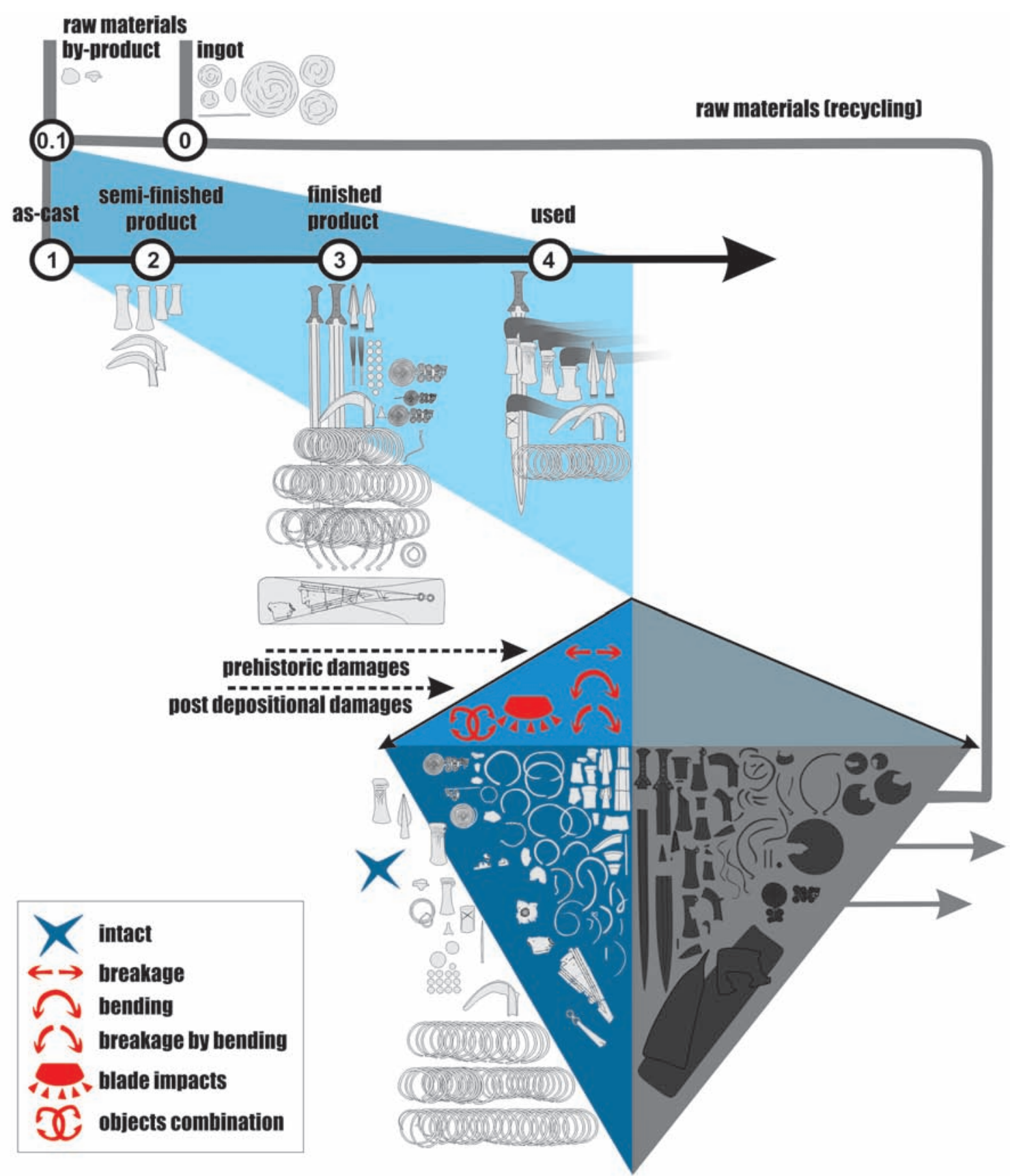

Fig. 3. Selection model of the Tatabánya-Bánhida II hoard (made after TARBAY 2018, 670-676). 
by their physical properties and certain ritual traditions. Breakages and manipulations were divided into detailed categories: 1. post-depositional, 2. prehistoric, 3. raw material partitioning, 4. usage damages. In the studied material, the first three seem to be dominant. Prehistoric breakages occurred on finished, unfinished and used objects alike. We believe that the fragmentation of raw material cannot primarily be related to deposition. They could have been made during casting at a pre-depositional location like casting workshop as part of the everyday foundry process. The fragmentation profile of the hoards was not uniform either and it depended on their geographical position, size, technological and typological selection.

\section{Typo-chronology}

The typo-chronological analysis of the finds was supplemented with lists of parallels and maps depicting the spatial appearance of all types. The aim of this approach was to provide the most complete, European-context analysis for the objects based on the current typo-chronological knowledge and the available literature. The results suggest that an individual horizon that can be synchronized with the Ha A2 phase is not possible to observe in the Hungarian material. The dating of the objects is various, ranging from the $\mathrm{Br} \mathrm{D} / \mathrm{Ha} \mathrm{A} 1$ to the $\mathrm{Ha} \mathrm{B} 2 / \mathrm{Ha} \mathrm{B} 3$. In several cases the 'Ha A2' overlapped with the Ha B1, which the author believes is an 'artificial pattern' caused by the fact that the von Brunn model was adopted without criticism by local researchers during the development of the Eastern European relative chronological schemes. Most of the studied hoards have been deposited at the time of the Ha B1, which support the theory of Svend Hansen. ${ }^{11}$ However, all hoards contained a significant number of 'archaic' objects, usually ornaments, knives and spearheads, which were much 'older' (Br D/Ha A1, Ha A1) from relative chronological point of view compared to the youngest finds in the hoards. Younger objects dated to the Ha B1 are bronze vessels, axes, winged axes and some of the sword. This refers to the possibility that the content of these hoards may have been accumulated for a long period of time or their content was continuously manipulated at the sites until they have been 'closed' at the Ha B1. Naturally, long relative chronological patterns are also affected by several distorting phenomena like synchronization problems of local chronological systems, metallurgical traditions, modern mixture of finds. Typo-chronological results also suggest that there are some hoards which compose independent groups based on their time of deposition (e.g. Br D-Ha A1: Velem IV, Zalaszentmihály-Pötréte, Tiszalök). For hoards that are containing large quantities of objects, a 'long' relative chronological pattern consisting of the material of several horizons are particularly characteristic (Fig. 4).

\section{Transdanubia}

The relative chronological position of the studied hoards from Transdanubia covered the chronological phase between the $\mathrm{Br} \mathrm{D} / \mathrm{Ha} \mathrm{A} 1$ and $\mathrm{Ha} \mathrm{B} 2 / \mathrm{Ha} \mathrm{B} 3$. Based on the time of deposition, the 'oldest' (Br D/Ha A1) assemblages are the Velem IV and Zalaszentmihály-Pötréte ornament set hoards. The time of deposition of the rest can be described as $\mathrm{Ha}$ A2/Ha B1, Ha B1, Ha B1/Ha B2, Ha B2/Ha B3. The complete relative chronological spectrum of most Transdanubian hoards started in the Br D/Ha A1 or in the Ha A1 (Fig. 4). The Transdanubian assemblages showed also differences in respect of their selection of types, quantity of objects and technological features. A more coherent hoard group can be outlined in the territory of the Transdanubian Mountains. Two hoards with metallurgical character - Nagydobsza, 


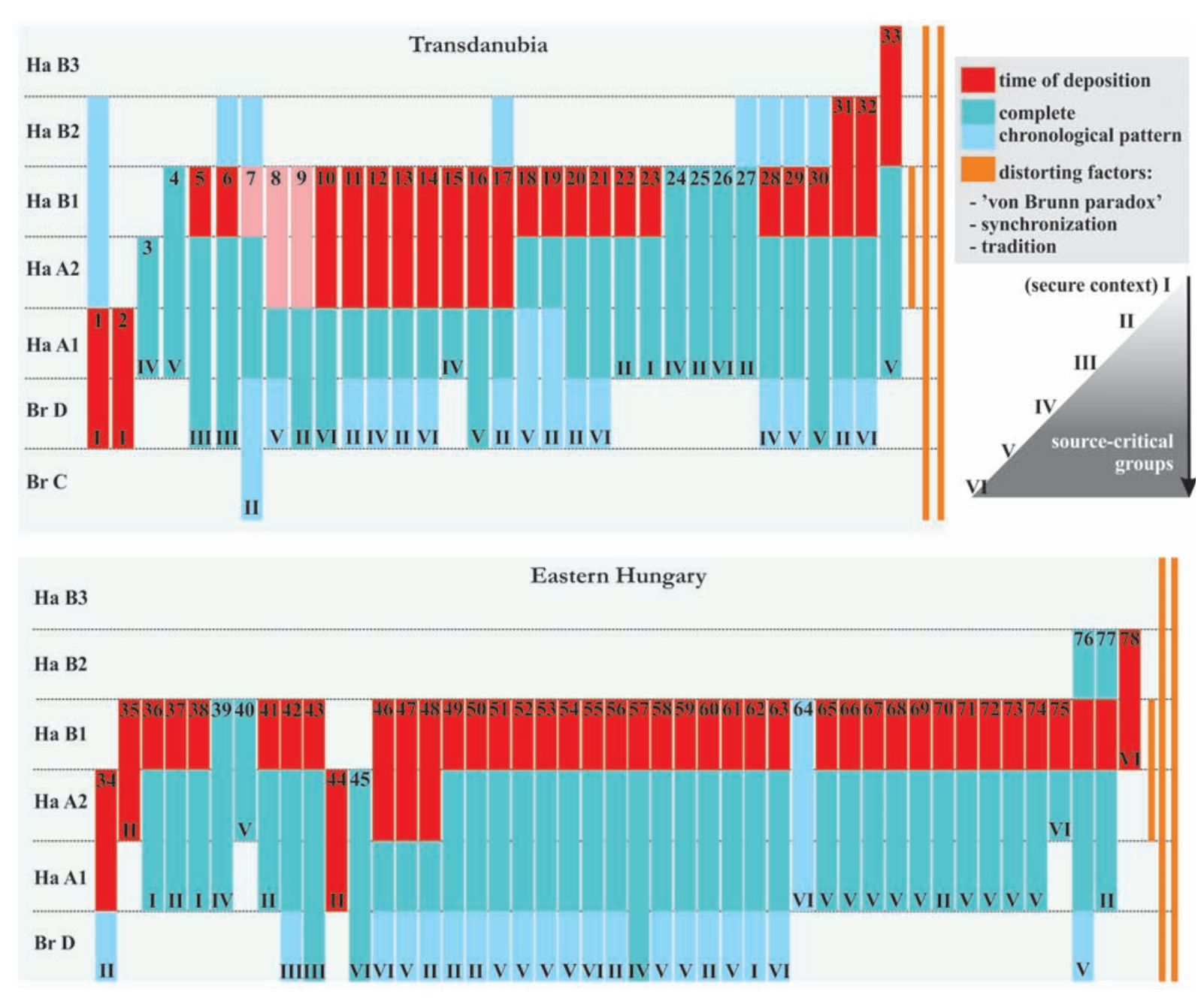

Fig. 4. The relative chronological position of the studied hoards: 1 - Velem IV, 2 - Zalaszentmihály, 3 - Szőkedencs, 4 - Fonyód II, 5 - Velem Ia-b, 6 - Nagydém Ia-b, 7 - Várvölgy I, 8 - Torvaj, 9 - Máriakéménd, 10 - Bátaszék, 11 - Csabdi, 12 - Tatabánya I, 13 - Kesztölc, 14 - Biatorbágy, 15 - Somogyszob, 16 - Sióagárd, 17 - Székesfehérvár, 18 - Tatabánya II, 19 - Siklósnagyfalu, 20 Gyermely-Szomor, 21 - Tatabánya III, 22 - Sümeg, 23 - Nagydobsza, 24 - Meszlen, 25 - Oroszlány, 26 - Lesenceistvánd Ia, 27 - Lesenceistvánd II, 28 - Lesenceistvánd Ib, 29 - Szombathely, 30 - Badacsonytomaj, 31 - Lovasberény, 32 - Tata-Dunamellék, 33 - Mohács, 34 - Tiszalök, 35 - Nyíregyháza III, 36 - Krasznokvajda, 37 - Szabolcsveresmart/Döge, 38 - Tuzsér, 39 - Szihalom, 40 - Hatvan, 41 Nyírpazony, 42 - Hódmezővásárhely, 43 - Hajdúböszörmény-Hetven-laponyag, 44 - Tiszabercel, 45 - Sarkad, 46 - Balassagyarmat, 47 - Napkor, 48 - Zsáka I, 49 - Hévízgyörk, 50 - Ecseg, 51 - Borsodgeszt, 52 - Szendrőlád, 53 - Zsujta, 54 - Jászkarajenő, 55 - Gelénes/Téglás, 56 - Buj, 57 - Pusztadobos, 58 - Tiszaszőlős I, 59 - Tiszavasvári II, 60 - Gáborján, 61 - Nagyrábé, 62 - Zsáka II, 63 - Szarvas vidéke, 64 - Edelény, 65 - Borsodbóta, 66 - Nyíregyháza V, 67 - Mérk, 68 - SzabolcsSzatmár-Bereg County, 69 - Kenderes, 70 - Debrecen III, 71 - Nádudvar II, 72 - Vésztő, 73 - Cserebökény, 74 - Szentes I, 75 - Jászdózsa, 76 - Debrecen II, 77 - Szajla, 78 - Isaszeg.

Siklósnagyfalu) shows particularly close relations regarding the typological and technological aspects of the selected types. A strong metallurgical character is also present in several of the studied Transdanubian hoards, which have raw material components consisting of partitioned ingots, by-products selected directly from casting workshops. The raw material component can dominate an assemblage (e.g. Csabdi) or it can be manifested through one symbolic object (e.g. Oroszlány). The deposition of multiple ornaments here is also dominant. Some of these objects compose clear sets, e.g. fibulae pairs, Type Lovasberény rings, phalerae 
and knobs. Additional elements in larger quantities are axes and sickles, in certain cases broken swords or spearheads. A correspondence analysis made after the submission of the dissertation also supported the above results. Those hoards, which were suitable for statistical analysis were dominated by raw materials or ornament. The coherent group on the territory of the Transdanubian Mountains were also visible (Fig. 5.A).

The 'cultural connections' of these hoards are hard to interpreted as one unit, since their time of accumulation and deposition differs. Based on the typo-chronological analysis, main areas related to the studied Transdanubian hoards are the North Bohemian Basin and Moravia, the Alps, the region of the Drava and Sava Rivers and the territory of Bosnia and Hercegovina. Some of the hoards also contained unique finds, showing clear relations towards Northeastern Hungary and Germany or the Baltic area (e.g. amber beads from Zalaszentmihály-Pötréte).

\section{Eastern Hungary}

The analysis of the East Hungarian assemblages also did not support the existence of an independent Ha A2 horizon. The 'earliest' assemblages can be dated to the Br D-Ha A (Sarkad I, Tiszalök) and Ha A (Tiszabercel). The rest of the finds were deposited in the Ha A2/Ha B1, Ha B1 or $\mathrm{Ha} \mathrm{B} 1 / \mathrm{Ha} \mathrm{B} 2$. Notable that many of them contained objects, which are belong to the $\mathrm{Br} \mathrm{D}$, $\mathrm{Ha} \mathrm{A} 1$ or $\mathrm{Br} \mathrm{D} / \mathrm{Ha} \mathrm{A} 1$ periods from relative chronological point of view (Fig. 4).

Compared to Transdanubia, the quantity of the deposited finds is lower in Eastern Hungary. Uniform deposition pattern cannot be detected in studied Eastern Hungary material either. Pure sword hoards compose an independent group, which part of a supra-regional depositional pattern. ${ }^{12}$ A unique find is the Zsujta hoard, which contains set of weapons, ornaments and a bird protomé ('wagon part'), which has relations towards West and Northern Europe. The composition and the technological character of the Eastern hoards is diverse. Some assemblages are dominated by raw materials, while in other rather different finished and used tools (axes, sickles) were selected. Ornaments, especially rings are characteristic here. Combination of ornament sets (rings, pins, fibulae) can also be seen among the East Hungarian material (Fig. 5.B). In the northern and north-eastern regions, the deposition of intact objects was characteristic, the degree of fragmentation increased to south and southwestern direction. Similarly, to Transdanubia, the fragmentation was more characteristic to large hoards containing various types.

Since, the hoards from Eastern Hungary has different chronological 'layers' and their time of deposition was also pointed to different periods. The connections of the studied material were hard to describe within a uniform frame. The deposited objects showed connection with the north-eastern part of the Carpathian Basin and its neighbouring regions (e.g. South Poland, Ukraine). Besides local forms (e.g. Type Prejmer swords) objects related to Transdanubia and the Balkans can also be observed, which earliest chronological layer can be dated to the $\mathrm{Br} \mathrm{D} /$ Ha A1 (e.g. Type Nadap-Poljanci phalerae). Later variants are the sickles and the ornament combination of the Type Debrecen socketed axes. Hoards related to Transdanubia can be seen primarily in the territories of the Berettyó-Körös and Körös-Maros region. Even comparable technological and fragmentation patterns to Transdanubia can be observed here. Besides the above, North European, supra-regional (Type Jenišovice and Egyek cups, Type Vadena), Alpine (hammer-shaped ingot, Type Wilten belt hook) and South-German (winged axes) network of connections can be outlined. 

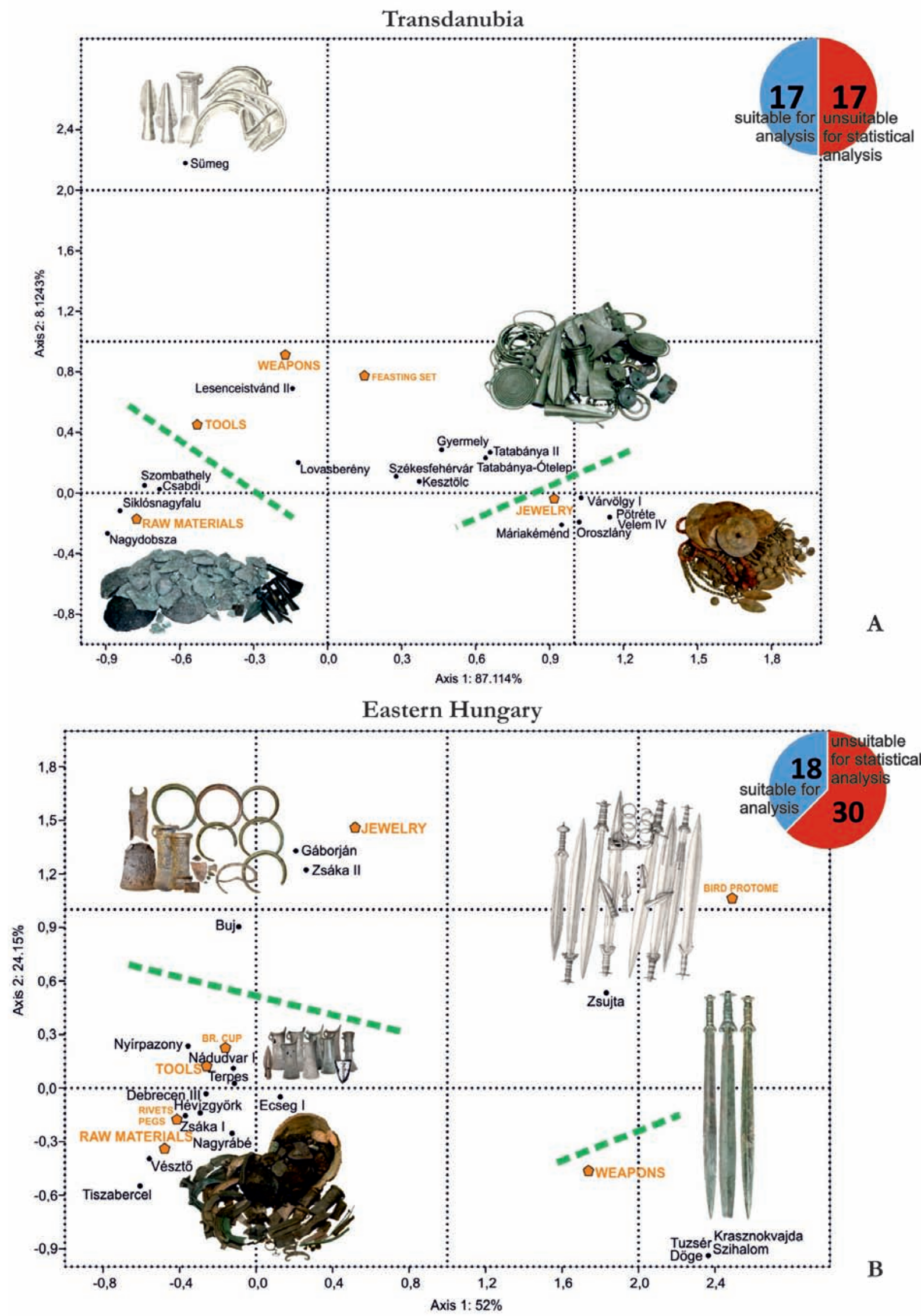

Fig. 5. Correspondence analysis of statistically representative hoards (made after the results of the dissertation). 


\section{Conclusions}

Based on the analyses of the assemblages from the territory of Hungary, we can conclude that a Ha A2 metal hoard horizon cannot be identified. The reasons for this conclusion are as follows:

- From source critical point of view, majority of the studied hoards are unsuitable for determining a fine 'transition horizon' or any horizon at all.

- The relative chronological position of the individual objects making up the hoards cannot be synchronized with the Ha A2 phase.

- In most cases, the complete chronological spectrum of the hoard assemblages extended beyond the Ha A2 phase.

- The assemblages time of deposition is clearly not the Ha A2, as except from a few 'older' Br D/Ha A1 and Ha A1 finds, they are terminated from relative chronological point of view in the $\mathrm{Ha} \mathrm{A} 2 / \mathrm{Ha} \mathrm{B} 1$ or $\mathrm{Ha} \mathrm{B} 1$ or even much later.

- The studied hoards showed typological relations, however they do not form a homogenous unit in terms of selection (technology, fragmentation, manipulations) but they are rather fall into individual pieces and smaller groups affected by certain region, typological selection or technological aspects.

- Most hoards that were previously associated with the Horizon Gyermely or Hortfundstufe III have a highly structured chronological selection, as they consist of materials from different periods. Besides obvious source critical factors (e.g. synchronization problems of Eastern European chronological systems, mixing of finds by antiquities dealers), the 'long chronological' patterns are reflected on accumulation mechanism of Carpathian hoards. It is possible that the finds were cumulated in households or metallurgical workshops for a long period of time and they have been selected to hoards at the time of deposition. Other scenarios like the continuous manipulation of the hoards content are also plausible. During this process, new elements were added to each hoard, some objects were taken out as tokens or selected elsewhere. Recycling of these the missing parts and finds are also highly plausible.

\section{References}

BRATu, O. 2009: Depuneri de bronzuri între Dunărea mijlocie şi nistru în secolele XIII-VII a. Chr. București.

VON BRUnN, W. A. 1968: Mitteldeutsche Hortfunde der jüngeren Bronzezeit. Römisch-Germanische Forschungen 29. Berlin.

Hampel, J. 1886: Trouvailles de l'Âge de Bronze en Hongrie. Budapest.

HAMPel, J. 1892: A Bronzkor emlékei Magyarhonban. II. Rész: a leletek statisztikája. Budapest.

HANSEN, S. 1994: Studien zu den Metalldeponierungen während der älteren Urnenfelderzeit zwischen Rhônetal und Karpatenbecken 1-2. Universitätsforschungen zur prähistorischen Archäologie 21. Bonn.

Hansen, S. 1996: Bemerkungen zur Zeitlichen Stellung der Hortfunde des Typus Gyermely. Archäologisches Korrespondenzblatt 26, 433-441.

Holste, F. 1951: Hortfunde Südosteuropas. Marburg/Lahn. 
Kemenczei, T. 1984: Die Spätbronzezeit Nordostungarns. Archaeologica Hungarica 51. Budapest.

KemenczeI, T. 1996a: Angaben zur Frage der endbronzezeitlichen Hortfundstufen im Donau-Theißgebiet. Communicationes Archaeologicae Hungaricae, 53-92.

Kemenczei, T. 1996b: Unpublished finds in the Prehistoric Collection of the Hungarian National Museum. In: Kovács, T. (eds): Studien zu Metallindustrie im Karpatenbecken und den benachbarten Regionen. Festschrift für Amália Mozsolics zum 85. Geburtstag. Budapest, 231-247.

Mozsolics, A. 1985: Depotfundhorizonte von Aranyos, Kurd und Gyermely. Budapest.

Tarbay, J. G. 2014: Late Bronze Age Depot from the foothills of the Pilis Mountains. Dissertationes Archaeologicae 3/2, 179-297.

Tarbay, J. G. 2015b: The Reanalysis of the Eponymous Hoard from Gyermely-Szomor and the Ha A2 Period in the Territory of Hungary. In: Rezi, B.-NÉmeth, E. R. (eds): Bronze Age Chronologies in the Carpathian Basin. Proceedings of the International Colloquium from Târgu Mureş 2-4 October 2014. Târgu Mureş, 311-371.

TARBAY, J. G. 2018: A gyermelyi típusú kincsek és koruk. ELTE Eötvös Loránd University- Institute of Archaeological Sciences. DOI 10.15476/ELTE.2018.167.

Turk, P. 1996: The Dating of Late Bronze Age Hoards - Datacija poznobronastodobnih depojev. In: TERŽAn, B. (ed.): Depojske in posamezne kovinske najdbe bakrene in bronaste dobe na Slovenskem - Hoards and Individual Metal Finds from the Eneolithic and Bronze Age in Slovenia. Katalogi in monografije/Catalogi et monographiae 29. Ljubljana, 89-124.

VAchtA, E. T. F. 2007: Studien zu den bronzezeitlichen Hortfunden des oberen Theissgebietes. Universitätsforschungen zur prähistorischen Archäologie 1959. Bonn.

VÁczI, G. 2014: A Sióagárd-leányvári kincslelet. Megjegyzések a gyermelyi horizont időrendjéhez. In: Anders, A.-BAlogh, Cs.-TÜrk, A. (eds): Avarok Pusztái. Régészeti tanulmányok Lőrinczy Gábor 60. születésnapjára - Avarum Solitudines. Archaeological studies presented to Gábor Lörinczy on his sixtieth birthday. Budapest, 43-57.

\section{Publications related to the $\mathrm{PhD}$ dissertation}

\section{Published}

TARbay, J. G. 2012: Újabb paszományos fibulák a Dunántúlról: Kesztölc és Dunaújváros (New passamenterie fibulae from Kesztölc and Dunaújváros in Transdanubia). Ösrégészeti Levelek/Prehistoric Newsletter 12, 115-136.

Tarbay, J. G. 2014: Late Bronze Age Depot from the foothills of the Pilis Mountains. Dissertationes Archaeologicae 3/2, 179-297.

Tarbay, J. G. 2015a: The Central European "Spiral Arm-Guard". Notes on the Bronze Age Asymmetrical arm-and anklets (A közép-európai „kézvédő spirál” Adatok a bronzkori asszimetrikus karés lábperecekről). Communicationes Archaeologicae Hungariae, 71-106.

Tarbay, J. G. 2015b: The Reanalysis of the Eponymous Hoard from Gyermely-Szomor and the Ha A2 Period in the Territory of Hungary. In: RezI, B.-NÉmETh, E. R. (eds): Bronze Age Chronologies in the Carpathian Basin. Proceedings of the International Colloquium from Târgu Mureş 2-4 October 2014. Târgu Mureş 2015, 311-371.

TARbAy, J. G. 2015c: A Late Bronze Age hoard and sickle-shaped pins from Fövenyes (Hungary, Veszprém County) (Késő bronzkori depó és sarló alakú tűk Fövenyesről (Magyarország, Veszprém m.)). Ösrégészeti Levelek/Prehistoric Newsletters 14, 84-118.

TARBAY, J. G. 2016a: Kopott markolatú kardok... A gyopárosfürdői késő bronzkori kardlelet a legújabb kutatások tükrében. Mozaikok Orosháza és vidéke mútjából 15, 3-25.

TARBAY, J. G. 2016b: The Late Bronze Age „Scrap Hoard” from Nagydobsza (Hungary, Baranya County): Part I. Communicationes Archaeologicae Hungariae, 87-146. 
TARBAY, J. G. 2017a: Égitestek, bronzkincsek, rituálék... Késő bronzkori fémleletek Hajdúböszörmény határából: Zelemér és Hetven-Laponyag (Celestial bodies, bronze hoards, rituals... Late Bronze Age metal finds from the surroundings of Hajdúböszörmény: Zelemér and Hetven-Laponyag). In: V. SzABó, G.-BÁLInt, M.-VÁczI, G.-LőRinczy, G. (eds): A második hajdúböszörményi szitula és kapcsolatrendszere - The second situla of Hajdúböszörmény and its relations. Studia Oppidorum Haidonicalium 13. Budapest-Hajdúböszörmény, 105-146.

Tarbay, J. G. 2017b: The Late Bronze Age Hoard from Oltárc Márki Hill. Analysis of prehistoric manipulations, selective fragmentation and non-ritual violence (Késő bronzkori depó Oltárc-Márki hegyről. Őskori manipulációk, szelektív és recens törések vizsgálata). Zalai Múzeum 23, 73-137.

Tarbay, J. G. 2017b: The Spear, the Hoard and the "Elusive Ornament". In: Kulcsár, G.-V. Szabó, G.Kiss, V.-VÁczi, G. (eds): State of the Hungarian Bronze Age Research. Proceedings of the conference held between $17^{\text {th }}$ and $18^{\text {th }}$ of December 2014. Ösrégészeti Tanulmányok/Prehistoric Studies 2. Budapest, 349-368.

Tarbay, J. G. 2019a: Disc cuirasses or costume sets? A Late Bronze Age ribbed "phalera" type from East-Central Europe (Panzerscheiben oder Bekleidungszubehör? Die spätbronzezeitlichen Phaleren mit Rippenzier aus Ostmitteleuropa). In: BÁNfFy, E.-P. BARNA, J. (eds): “Trans Lacum Pelsonem" Prähistorische Forschungen in Südwestungarn (5500-500 v. Chr.) - Prehistoric Research in South-Western Hungary (5500-500 BC). Castellum Pannonicum Pelsonense 7. Budapest-Leipzig-Keszthely-Frankfurt-Rahden/Westf., 367-384.

Tarbay, J. G. 2019b: On Selection in "Common Hoards". The Szajla Hoard and Some Related Finds from Late Bronze Age Carpathian Basin. In: M. S. PrzybyŁA, K. - Dzięgielewski, K. (eds): Chasing Bronze Age rainbows. Studies on hoards and related phenomena in prehistoric Europe in honour of Wojciech Blajer. Prace Archeologiczne - Studies 69. Kraków, 273-347.

\section{In press}

TARBAY, J. G. in press: Broken sword, damaged axes and partitioned ingots: New Late Bronze Age hoard from Hévízgyörk-Hegyi dülő. Váci Könyvek (accepted manuscript, 2019). 
